\title{
FOOD SAFETY ASPECTS IN BLOOD COCKLES (Tegillarca granosa) CULTURED OFF SELANGOR, PENINSULAR MALAYSIA
}

\author{
Wan Norhana M.N ${ }^{1}$., T. Yurimoto ${ }^{2}$, B. Intan Nurlemsha ${ }^{1}$, M. R. Roziawati ${ }^{1}$ and K. Saadon $^{3}$ \\ ${ }^{1}$ Fisheries Research Institute, 11960, Batu Maung, Penang, Malaysia \\ ${ }^{2}$ Japan International Research Centre for Agricultural Sciences, Tsukuba, Japan \\ ${ }^{3}$ Fisheries Biosecurity Lab, Lot 82, Jalan Caruthers, off Jalan Sultan Salahuddin, 50480, Kuala Lumpur, Malaysia \\ *Corresponding author: Wan Norhana bt. Md. Noordin \\ email: wannorhana@yahoo.com
}

Received: 10 June $2016 \quad$ Revised: 19 Oct 2016

Accepted: 2 Nov 2016

\begin{abstract}
This study evaluates some food safety aspects of the blood cockle (Tegillarca granosa) and its culture waters at Bagan Nakhoda Omar (BNO), Sungai Besar (SB) and Bagan Sungai Buloh (BSB) in Selangor. Samplings of cockles and seawater from the culture beds were carried out from Oct 2014 to Mar 2015 to analyse for fecal indicator bacteria, hepatitis A virus and saxitoxin in cockles and harmful phytoplankton and heavy metals in seawater. The results indicated that cockles from BNO, SB and BSB were of Class C category suggesting that the cockles could only be sold for human consumption after re-laying, followed by purification or heat treatment processes. Meanwhile, the cockle culture areas of BNO, SB and BSB were classified as 'conditionally approved'. The saxitoxin levels in cockle samples from BNO, SB and BSB were $0.12-0.80,0.05-0.25$ and $0.05-0.18 \mathrm{nmol} / \mathrm{g}$, respectively and hepatitis A virus was not detected in the cockels samples. Phytoplankton composition was dominated by the diatom group (>96\%). Pseudo-nitzhia spp. and Dinophysis caudata were commonly found but at low cell counts. The levels of $\mathrm{Cr}, \mathrm{Zn}, \mathrm{Cu}, \mathrm{As}$ and $\mathrm{Hg}$ were higher than the Malaysian standards while $\mathrm{Se}, \mathrm{Cd}$ and $\mathrm{Pb}$ were within the safe limits. Further investigation should be carried out to identify the pattern and source of pollution throughout a year so that appropriate and cost-effective corrective actions could be taken to prevent future pollution and adverse effect to the public.
\end{abstract}

Keywords: food safety, phytoplankton, cockles, culture waters, Selangor

ABSTRAK Kajian ini menilai beberapa aspek keselamatan makanan bagi kerang (Tegillarca granosa) dari
Bagan Nakhoda Omar (BNO), Sungai Besar (SB) dan Bagan Sungai Buloh (BSB), Selangor. Persampelan kerang
dan air laut dari kawasan ternakan kerang dibuat daripada Okt 2014 hingga Mac 2015 untuk diuji kandungan
bakteria penunjuk pencemaran najis, virus hepatitis A dan saxitoxin dalam kerang serta komposisi fitoplankton dan
logam berat dalam air laut. Keputusan yang didapati menunjukkan kerang dari BNO, SB dan BSB adalah dari Kelas
$\mathrm{C}$ yang bermaksud kerang dari sini hanya boleh dipasarkan selepas dipindah dan dibiarkan dalam perairan yang
bersih diikuti dengan samada depurasi atau proses pemanasan. Perairan ternakan kerang di BNO, SB dan BSB
dikategorikan sebagai lulus bersyarat. Paras saxitoxin dalam sampel kerang dari BNO, SB dan BSB adalah 0.12-
0.80, 0.05-0.25 dan0.05-0.18 nmol/g, masing-masing sementara virus hepatitis A tidak dikesan dalam sampel
kerang. Komposisi fitoplankton bagi semua kawasan persampelan didominasi oleh kumpulan diatom (> $96 \%)$
daripada jumlah kepadatan fitoplankton. Mikroalga penghasil toksin, Pseudo-nitzhia spp. dan Dinophysis caudata
ditemui di setiap kawasan persampelan tetapi pada kepadatan yang rendah. Paras logam Cr, Zn, Cu, As dan Hg
dalam air laut adalah lebih tinggi daripada paras yang dibenarkan dalam Piawaian Malaysia manakala Se, Cd dan Pb
dikesan, tetapi tidak melebihi piawaian. Kajian lanjut sepanjang tahun perlu dijalankan untuk mengenalpasti corak
dan punca pencemaran najis supaya tindakan pembetulan yang sesuai dan kos efektif dapat diambil agar pencemaran
yang lebih teruk serta kesan negatif terhadap pengguna dapat dihalang.

\section{INTRODUCTION}

Selangor is one of the major blood cockle (Tegillarca granosa) producing states in Malaysia. According to the Annual Fisheries Statistics, the harvest of cockles in Selangor remained at less than 10,000 tons in early 2000 but gradually increased from 2008 attaining a record harvest of 42,000 tons in 2010, produced from about 43 active production plots (Annual Fisheries Statistic, 2008; 2010). However, the production of 
cockles had declined to about 25,000 tons in 2011 and further plunged to 5,407 metric tonnes in 2013. Meanwhile, the productivity of the culture plots along the coastal areas of Selangor had also deteriorated from 14.3 tons/hectare in 2010 to 2.9 tons/hectare in 2013 (Alias, 2015). The decline in cockle production in Selangor had been closely associated with pollution of the coastal waters from the intensive agricultural activities, the reduction of mudflats due to erosion of fine mud, deterioration of sea bed surfaces due to decline in the flow rate of rivers as a result of dam and reservoir developments and overstocking of cockle seed (Yurimoto et al., 2014). Other studies had associated high ammonia concentrations in the culture waters with the decline in cockle production (Mohd Fadzil et al., 2010; Shimoda, 2015).

The Department of Fisheries Malaysia and the Japanese International Reseach Cooperation (JIRCAS) initiated a research collaboration in 2011 to investigate the problems. A research project related to the declining cockle industry entitled "the development of a sustainable management plan for blood cockle culture deploying the carrying capacity analysis" was planned and executed. One of the components of this project was to assess the food safety aspects of the cockles for human consumption and the phytoplankton abundance especially the toxin producing algae and heavy metals contents in the cockles culture waters. This is important as cockles are prone to accumulate contaminants such as viruses, bacterial pathogens and toxic phytoplankton present in water due to their filter feeding behaviour. Thus, harvesting cockles from areas exposed to fecal pollution or areas with high numbers of toxic phytoplankton may pose health hazards to the public when they consume cockles (Ahmed, 1991).
To our knowledge, there is very little published information on the safety aspects of cockles or the sanitary quality of cockle culture waters from Selangor although some of the areas are being monitored under the National Shellfish Santitation Program by the Department of Fisheries, Malaysia. The physicochemical water quality of cockle culture areas from Kuala Selangor has been considerably described in detail (Yurimoto et al., 2014; Mohd Fadzil et al., 2010; Shimoda, 2015). To acquire a complete baseline data for the cockle industry in Selangor, it will be valuable to assess the biological quality of the culture areas and the safety aspects of the cockles harvested for consumption. Hence, this study is carried out to i) determine the fecal concentration in cockle tissues and seawater from the cockle culture beds off Selangor ; ii) detect the presence of Hepatitis A virus in cockles tissues iii) detect the presence of Paralytic Shellfish Toxin (PSP) in cockles tissues; iv) determine the heavy metal levels in cockles tissues and v) determine the presence of potential harmful microalgae in seawater.

\section{MATERIALS AND METHODS}

\section{Sampling}

Seawater and shellfish (blood cockles, $T$. granosa) samples were collected from 3 stations; i) Bagan Nakhoda Omar (N $3^{\circ} 44^{\prime}$ 21.66”, E 100 52' 30.72”), ii) Sungai Besar (N 3 $3^{\circ} 38$ ' 53.88', E 10' 58' 46.38') in Sabak Bernam district and iii) Bagan Sungai Buloh (N 3 15' 31.14", E 101 17' 9.18”) in Kuala Selangor district, Selangor, Malaysia (Fig. 1) on a monthly basis from October 2014 to March 2015. Seawater was collected using sterile bottle $(500 \mathrm{ml})$ in triplicate from each station for bacterial analysis. Cockles from each station were sampled using a core with a long handle (basket size: $60 \mathrm{~cm}$ wide, $15 \mathrm{~cm}$ high, $30 \mathrm{~cm}$ 
deep; $1.5 \mathrm{~cm}$ mesh). The core was dragged for one to two minutes on the cockle bed until half full and brought up to the surface, rinsed vigorously in seawater to remove mud before placing the cockles on the boat deck. A total of 20-30 individuals were randomly selected and placed in a sterile bag for bacterial, hepatitis A virus and biotoxin analysis. This process was repeated three times. Sub surface water samples for heavy metal from each station were collected using polypropylene Niskin bottles $(100 \mathrm{ml})$. Surface seawater samples from the 3 selected locations were collected using a water sampler and transferred to $1 \mathrm{~L}$ sampling bottles. A few drops of Lugol's solution were added to the seawater samples for fixing and staining the phytoplankton present. The samples were packed in icecooled insulated box and transported back to the laboratory to be analysed within $24 \mathrm{~h}$.

Fecal coliform (FC) and E. coli (EC) analysis in seawater and shellfish samples
Cockle samples were rinsed clean with tap water and shucked using a sterilized knife. A total of $25 \mathrm{~g}$ of the cockle flesh was transferred to a sterile blender (Waring, USA) and a 1:10 dilution was prepared with a sterile phosphate buffer solution, followed by blending for $1 \mathrm{~min}$. Serial dilution was performed and $1 \mathrm{ml}$ of the homogenate was inoculated on a Petrifilm (3M) to enumerate FC and EC. The analysis of FC in seawater was carried out using the Most Probable Number (MPN) method as described in the APHA (1998). FC and EC in shellfish were determined according to MPN methods as detailed out in the APHA (2001). The shellfish culture waters in Selangor were classified according to a classification criteria as described by the US National Shellfish Sanitation Program (2013) (Table 1). Meanwhile the European Committee Directives (1991) (Table 2) was used to classify the cockles quality. The one-way analysis of variance (ANOVA) was performed on all data sets using the SPSS Version 16.0. (Chicago, SPSS Inc.) at 95\% confidence level.

Table 1: Shellfish water classification criteria according to the US NSSP.

\begin{tabular}{ll}
\hline Classification & Criteria \\
\hline Approved areas & $\begin{array}{l}\text { When under the most unfavourable meteorological, hydrographic, seasonal or point-source } \\
\text { conditions, the FC counts do not exceed } 14 / 100 \mathrm{ml} \text { and } \leq 10 \% \text { of the samples exceed a FC } \\
\text { MPN of } 43 / 100 \mathrm{ml} \text {, for a five-tube decimal dilution test. At least } 15 \text { samples must be } \\
\text { analysed. }\end{array}$ \\
Conditionally approved areas & $\begin{array}{l}\text { When there are specific, predictable events (such as rainfall) that can cause an area to exceed } \\
\text { the water quality standards. The area is approved for shellfish harvest unless such an event } \\
\text { occurs, at which time it is closed for harvest for a period of time pre-determined by the State. }\end{array}$ \\
& $\begin{array}{l}\text { Areas with conditionally approved status must meet the standards set forth by the NSSP (see } \\
\text { under approved status) outside of the specific, predictable events. Shellfish harvest is }\end{array}$ \\
& allowable in these areas when a closure is not in place. \\
Restricted areas & $\begin{array}{l}\text { When the waters are subjected to limited amounts of pollution such that shellfish must be } \\
\text { depurated or relayed prior to sale. Under the most unfavourable meteorological, }\end{array}$ \\
hydrographic, seasonal or point-source conditions, water samples should not have total \\
coliforms levels in excess of 700 per 100 ml with less than $10 \%$ of samples exceeding \\
2,300/100 ml for a 5 tube MPN. In addition, FCs must not exceed $88 / 100$ ml with $\leq 10 \%$ of \\
samples exceeding 260 per 100 ml for a 5 tube MPN. \\
When the waters are subject to intermittent pollution which make them temporarily \\
unsuitable as a source of shellfish for depuration or relaying. The waters are closed for \\
harvesting until they can meet the sanitary criteria for restricted areas.
\end{tabular}




\begin{abstract}
Prohibited areas $\quad$ When the level of pollution is such that shellfish are likely to be unfit for human consumption even after depuration or relaying. The harvesting of shellfish is banned from such waters.

Unclassified areas $\quad$ When no sanitary survey has been conducted. Harvesting of shellfish from such areas is banned.
\end{abstract}

Table 2: EC shellfish directives 91/492/EEC

\begin{tabular}{|c|c|c|c|}
\hline \multicolumn{2}{|c|}{ Classification } & Permitted levels & Outcome \\
\hline A & $<230$ & $\begin{array}{l}\text { Less than } 230 \mathrm{EC} / 100 \mathrm{~g} \text { flesh or } \\
\text { Less than } 300 \mathrm{FC} / 100 \mathrm{~g} \text { flesh }\end{array}$ & May go direct for human consumption \\
\hline B & $<4,600$ & $\begin{array}{l}\text { Less than } 4,600 \mathrm{EC} / 100 \mathrm{~g} \text { flesh } \\
\text { (in } 90 \% \text { of the samples) or } \\
\text { Less than } 6,000 \mathrm{FC} / 100 \mathrm{~g} \text { flesh (in } \\
90 \% \text { of the samples) }\end{array}$ & $\begin{array}{l}\text { Must be depurated, heat treated or } \\
\text { relayed to meet category A requirement }\end{array}$ \\
\hline $\mathrm{C}$ & $<46,000$ & $\begin{array}{l}\text { Less than } 60,000 \mathrm{FC} / 100 \mathrm{~g} \text { flesh } \\
\text { (in } 90 \% \text { of the samples) } \\
\text { Less than } 46,000 \mathrm{EC} / 100 \mathrm{~g} \text { flesh }\end{array}$ & $\begin{array}{l}\text { Must be relayed for a period of at least } 2 \\
\text { months, followed where necessary by } \\
\text { treatment in a purification centre to meet } \\
\text { category A requirements }\end{array}$ \\
\hline
\end{tabular}

Unsuitable for production

\section{Hepatitis A virus (HAV) analysis}

The RNA extraction of the Hepatitis A virus from the cockle meat was carried out using the RNeasy® kit (Qiagen, Hilden, Germany) while the Qiagen ${ }^{\circledR}$ One-Step RT-PCR kit (Qiagen, Hilden, Germany) was used for the detection of HAV as described in Goswami et al. (1993). Hepatitis A Virus (Enterovirus 72), cytopathic HM 175 (Clone 2) in infected cell lysates obtained from the American Type Culture Collection (ATCC) (Manassas, VA, USA) was used as a positive control. Reverse Transcriptase PCR conditions: reverse transcription at $50^{\circ} \mathrm{C} / 30$ min; initial $\mathrm{PCR}$ activation at $95^{\circ} \mathrm{C} / 15 \mathrm{~min}$; 3-step cycling-denaturation at $94^{\circ} \mathrm{C} / 40 \mathrm{~s}$, annealing at $49^{\circ} \mathrm{C} / 40 \mathrm{~s}$ and extension at $72^{\circ} \mathrm{C} / 60 \mathrm{~s}$ for $25-40$ cycles. Primers used were;

5'ATGCATCAACATGGATTCATCTCCT

GG3' and
5'CACTCATGATTCTACCTGCTTCTCTA ATC3'

\section{Paralytic Shellfish Toxin (PSP) analysis}

A total of $25 \mathrm{~g}$ of cockle tissues topped up with $0.1 \mathrm{M} \mathrm{HCL}$ (made up to $50 \mathrm{ml}$ ) in a falcon tube was homogenized. The homogenate was boiled for $5 \mathrm{~min}$ and left to cool at room temperature. The homogenate was centrifuged at $3000 \mathrm{rpm}$ for $5 \mathrm{~min}$ at $25^{\circ} \mathrm{C}$. The PSP toxin was extracted from the supernatant using the $\mathrm{S}$ Kit ELISA for Paralytic Shellfish toxin. The concentratations of PSP toxin were quantified according to the method provided by the kit manufacturer (S Kit ELISA).

\section{Harmful phytoplankton identification}

In the laboratory, the seawater samples were filtered through a $20 \mu \mathrm{m}$ pore size plankton 
net and each of the concentrated samples was diluted to $100 \mathrm{ml}$. A volume of $1 \mathrm{ml}$ concentrated sample was transferred to a Sedgewick Rafter Cell Counter using a $1 \mathrm{ml}$ micropipette (Eppendorf Research). The samples were viewed under an Olympus IX51 inverted microscope (Olympus, Tokyo, Japan) at 20x magnification and cells counted. Harmful phytoplanktons were identified to the lowest taxa based on the morphological descriptions provided by Balech (1995) and Omura et al. (2012).

\section{Heavy metal analysis}

In the laboratory, the seawater samples were immediately filtered through a nylon filter paper $(0.45 \mu \mathrm{m}, 4 \mathrm{~mm}$ diameter, Acrodisc (USA)) to remove the suspended particles. A volume of $500 \mu \mathrm{l}$ Nitric Acid (1\%) was added to the filtered seawater sampel to reduce the $\mathrm{pH}$ to less than 2. Sample preparation for heavy metal analysis was carried out as described in the EPA Method 200.8 (1994) and 6020 (CLP-M) (1998). The concentration of various heavy metals was determined using an Inductive Coupled Plasma Mass Spectrometer (ICP - MS) CX7500. A total of 8 metals: chromium $(\mathrm{Cr})$, zinc $(\mathrm{Zn})$, copper $(\mathrm{Cu})$, arsenic $(\mathrm{As})$, selenium $(\mathrm{Se})$, cadmium $(\mathrm{Cd})$, mercury $(\mathrm{Hg})$ and lead $(\mathrm{Pb})$ were examined.

\section{RESULTS AND DISCUSSION}

The geometric mean of FC counts in the seawater samples from the three stations along the coastal waters off Selangor is shown in Figure 2. There is no significant difference $(p<0.05)$ between FC counts in seawater samples from $\mathrm{BNO}, \mathrm{SB}$ and $\mathrm{BSB}$ although the FC counts in SB was significantly lower $(\mathrm{p}<0.05)$ than the $\mathrm{FC}$ counts in BNO and BSB. All of the seawater samples from BNO and BSB had FC readings that exceeded $43 \mathrm{MPN} / 100 \mathrm{ml}$ which is the criteria used for any shellfish culture area under the US NSPP (2013), and in this case $>90 \%$ of seawater samples from SB exceeded the stipulated value. There was no significant difference $(p>0.05)$ for $F C$ counts in seawater samples at different sampling months. The FC counts was higher in Jan, Feb Mac compared to Oct, Nov and Dec. Although from mid Oct to Mar was the northeast monsoon which usually brings heavy rainfall in the east coast, Jan to Mac on the west coast is the beginning of hot and dry season. Elevation of FC counts especially during summer has been reported by others (Latha \& Ramachandra, 2013; Sasikumar \& Krishnamoorthy, 2010). This is not surprising as FC has adapted from living inside the intestinal tract of the warm blooded animals thus making them able to survive better in warmer waters. Based on the NSSP, cockle culture areas at BNO, SB and BSB are categorized as "conditionally approved" based on their median FC counts which exceeded $14 \mathrm{MPN} / 100 \mathrm{ml}$ and more than $10 \%$ of the samples exceeded of 43 MPN/100 ml. Our observation is supported by Othman et al. (2014) who reported a high total coliform and E. coli counts in Selangor River and its tributary. They observed the highest E.coli concentration in the urban area (Rawang sub basin) followed by industrial, residential and agricultural areas. Their results revealed that, the Selangor river water at Rawang sub basin was greatly affected by microorganism attributed to point and non-point sources of pollution. 


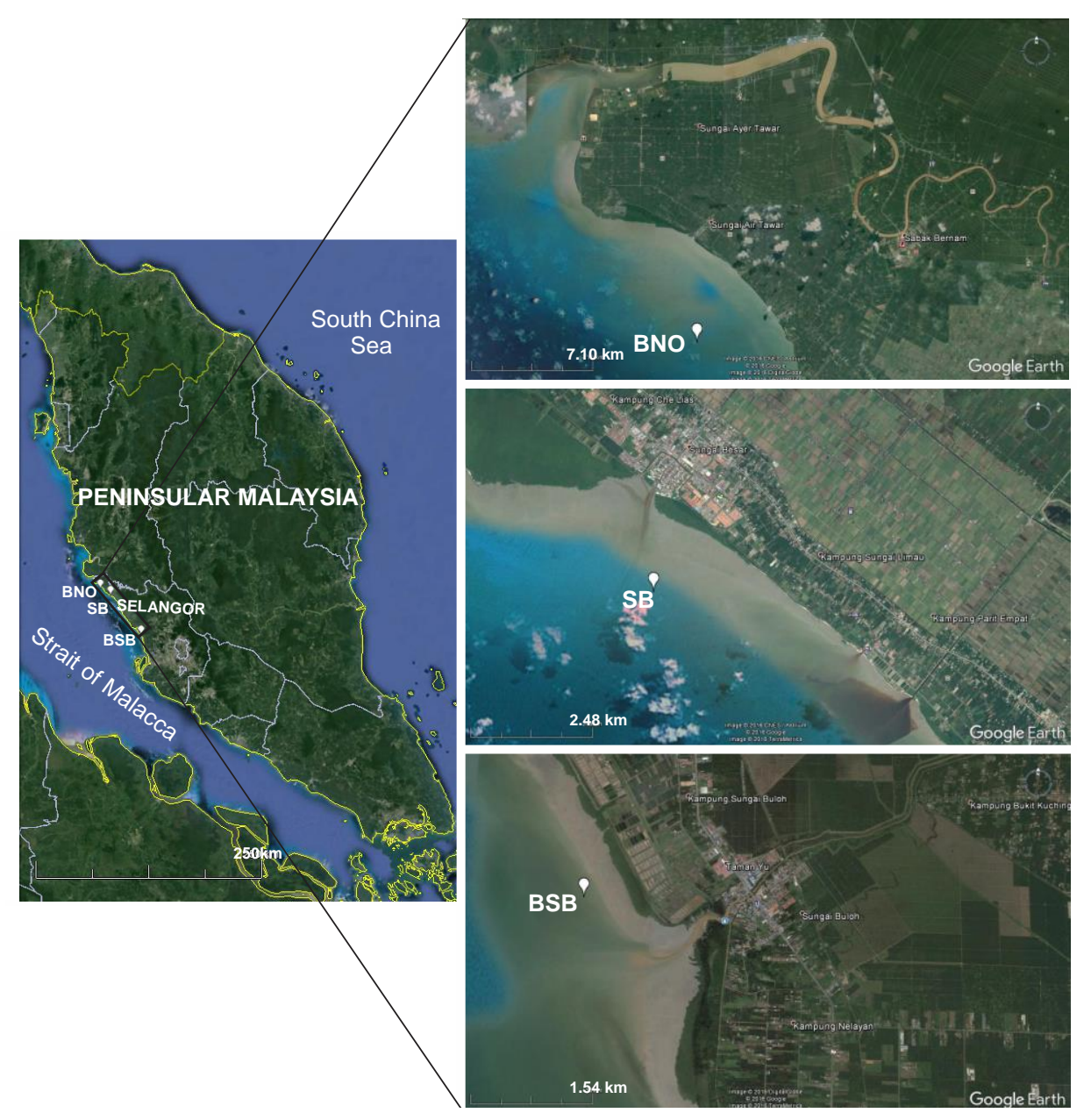

Figure 1: Map of study areas at Bagan Nakhoda Omar, Sungai Besar and Bagan Sungai Buloh.

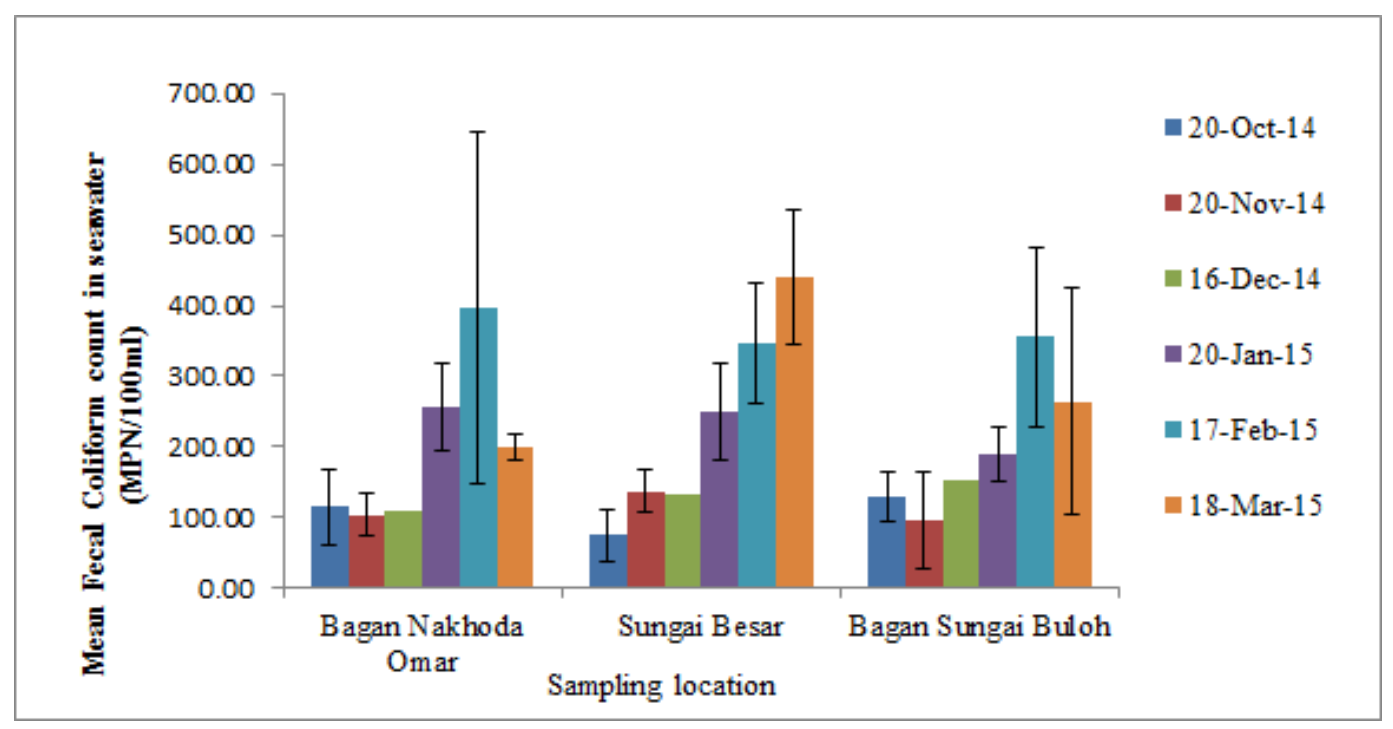

Figure 2: Fecal coliform (FC) counts in seawater from Bagan Nakhoda Omar, Sungai Besar and Bagan Sungai Buloh from October 2014 to March 2015 
The mean FC counts in cockles from $\mathrm{BNO}, \mathrm{SB}$ and BSB are presented in Figure 3. There was no significant differences ( $p>$ 0.05 ) in FC counts in cockles from $\mathrm{SB}, \mathrm{BNO}$ and BSB or for different sampling dates although the cockles from SB generally had lower FC counts as compared to BNO and BSB. BNO and BSB are located very near to the river mouth. This might be the source of constant influx of FC into the waters. Meanwhile SB is located adjacent to a very densely populated area. Based on the Directives 91/492/EC, cockles harvested from BNO, SB and BSB fall under Class C as the samples harboured $\mathrm{FC}$ of more than $6,000 / 100 \mathrm{~g}$ in $90 \%$ of the samples tested (Table 2). As such, shellfish harvested from these areas should not be consumed raw.

$\mathrm{SB}$ is one of the stations monitored under the National Shellfish Sanitation program by the DOF and had been classified as Class B during the years 1999 to 2012 (unpublished data). However in 2013 and 2015 (this study) it is categorised as Class C.
The finding indicates that the quality of cockles from SB had been deteriorating. This could be due to the anthropogenic activities (agricultural activities, human settlement) that have been affecting the physicochemical aspects of the water quality as reported by Yurimoto et al. (2014), Othman et al. (2014), and Shimoda (2015). Unfortunately there was no data for the classification of BNO and BSB for comparison under the same program.

Hepatitis A virus was not detected in any of the shellfish samples examined. The very low detection of HAV in shellfish from this study agrees with other reports (Tek, 2009; Vilarino et al., 2009). The saxitoxin content in cockle samples from BNO, SB and BSB ranged from 0.12-0.80, 0.05-0.25 and $0.05-0.18 \mathrm{nmol} / \mathrm{g}$, respectively which were within the safety limit of $1.6 \mathrm{nmol} / \mathrm{g}$ (Table 3). However, the saxitoxin producing microalgae was not detected in this study.

Table 3: Saxitoxin concentrations in cockle tissues from Bagan Nakhoda Omar, Sungai Besar and Bagan Sungai Buloh, Selangor

\begin{tabular}{llc}
\hline Sampling Location & Date of sampling & PSP concentration $(\mathbf{n m o l} / \mathbf{g})$ \\
\hline Bagan Nakhoda Omar & $20 / 10 / 2014$ & $0.12 \pm 0.02$ \\
$20 / 11 / 2014$ & $0.12 \pm 0.01$ \\
$16 / 12 / 2014$ & $0.16 \pm 0.02$ \\
$20 / 1 / 2015$ & $0.14 \pm 0.02$ \\
$17 / 2 / 2015$ & $0.80 \pm 0.06$ \\
$18 / 3 / 2015$ & $0.20 \pm 0.00$ \\
Sungai Besar & $20 / 10 / 2014$ & $0.11 \pm 0.03$ \\
& $20 / 11 / 2014$ & $0.08 \pm 0.02$ \\
& $16 / 12 / 2014$ & $0.25 \pm 0.08$ \\
& $20 / 1 / 2015$ & $0.05 \pm 0.01$ \\
Bagan Sungai Buloh & $17 / 2 / 2015$ & $0.08 \pm 0.02$ \\
& $18 / 3 / 2015$ & $0.06 \pm 0.01$ \\
& $20 / 10 / 2014$ & $0.16 \pm 0.05$ \\
& $20 / 11 / 2014$ & $0.08 \pm 0.04$ \\
& $16 / 12 / 2014$ & $0.18 \pm 0.09$ \\
\hline
\end{tabular}



$20 / 1 / 2015$
$0.15 \pm 0.04$
$17 / 2 / 2015$
$0.05 \pm 0.00$
$18 / 3 / 2015$
$0.05 \pm 0.01$

Cell densities of the potentially harmful microalgae at BNO, SB and BSB are shown in Figure 3. The phytoplankton community was dominated by the diatom group which is common in the coastal waters which comprised of more than $96 \%$ of the total cell count at BNO, SB and BSB. Similar observation was recorded in previous studies where they noted diatoms to be the most abundant group of marine phytoplankton (Majbrit, et al., 2004; Booyapiwat, 1997; Carter et al., 2005). Diatoms are known for their rapid growth responses to nutrient enrichments as compared to others phytoplankton groups (Polat, 2007). Diatom proliferation also depends on the nutrient ratio and not just the nutrient concentration. However, most of the diatoms are non-toxic and serve as a primary food source for the filter-feeding cockles. Pseudo-nitzchia spp. was observed in low densities at all the sampling sites throughout the sampling period, with a maximum of $0.25 \%$ of the total count. Although Pseudo-nitzschia spp. has been reported to be widely distributed in Malaysian waters (Lim et al, 2012; Teng et al., 2013), their presence in cockle culture waters need to be heeded as almost one third of this species produce domoic acid, a type of neurotoxin that causes amnesic shellfish poisoning (ASP). However, to date, there is no incidence of ASP reported in Malaysia, although a toxic species, $P$. kodamae had been reported in the Straits of Malacca (Tong, 2014). 


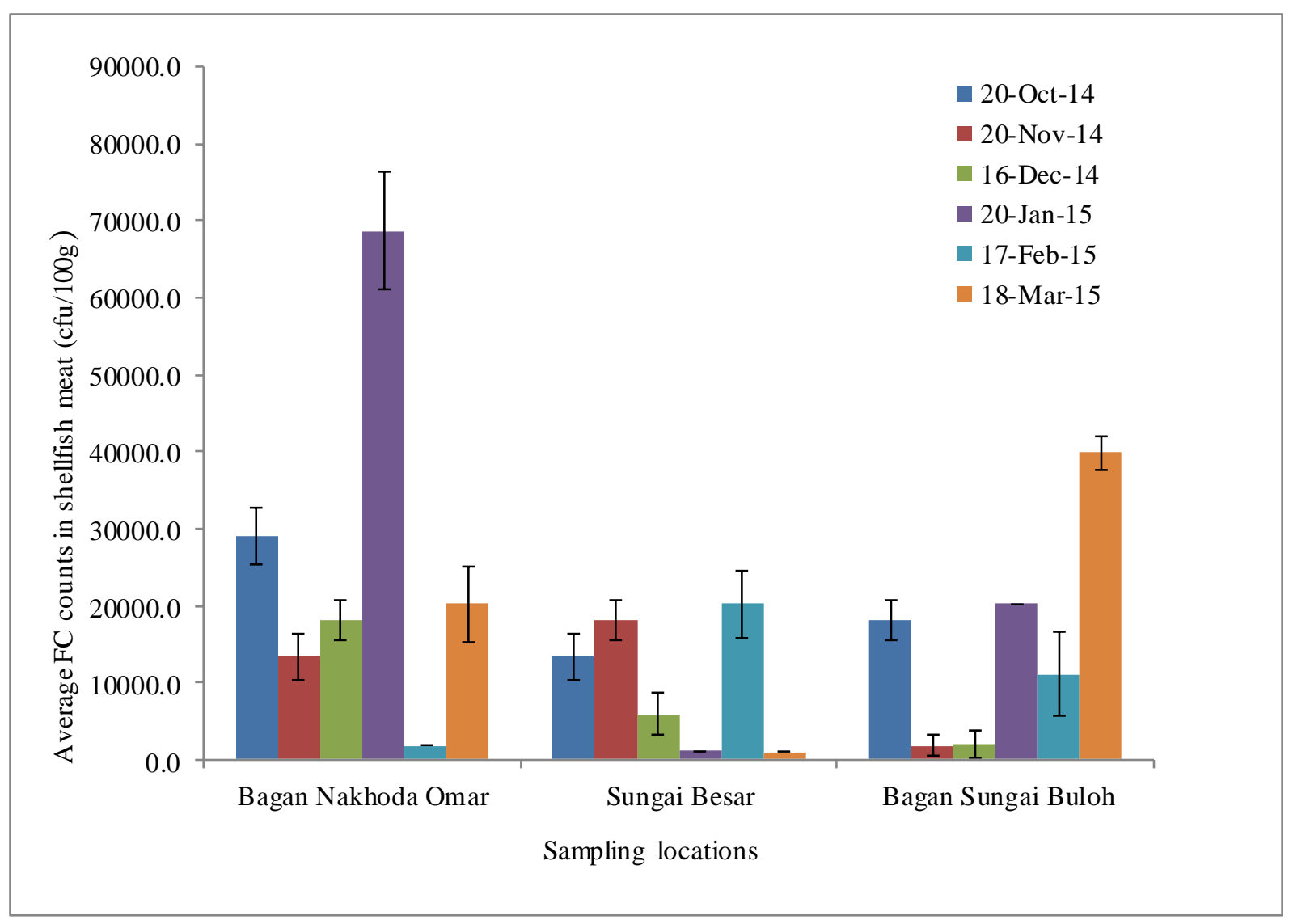

Figure 3: Fecal coliform (FC) counts in cockles from Bagan Nakhoda Omar, Sungai Besar and Bagan Sungai Buloh from October 2014 to March 2015

Besides Pseudo-nitzhia spp., other potentially shellfish poisoning toxin producers found in $\mathrm{BNO}, \mathrm{SB}$ and $\mathrm{BSB}$ were Dinophysis spp. and Prorocentrum micans. D. caudata was present in BNO and SB with the highest cell density of 500 cells $\mathrm{L}^{-1}$ and 100 cells $\mathrm{L}^{-1}$ respectively, while the other Dinophysis spp. was only present at SB. The presence of $D$. caudata had been reported in the coastal waters off Malacca (MohammadNoor, et al., 2007), Sg. Jarum Mas, Perak (Roziawati and Faazaz, 2011) and Selat Tebrau, Johor (Toh et al., 2013). Several species of Dinophysis produce okadaic acid, a toxin that causes gastrointestinal illness, even at low cell densities $\left(<10^{3}\right.$ cells $\left.\mathrm{L}^{-1}\right)$. Even at low densities, D. caudata had been known to produce persistently low concentrations of Diarrhetic Shellfish Poisoning (DSP) toxins in the green mussels (Perna viridis) off Singapore coast (Holmes and Teo, 2002). In Malaysia, no incidence of DSP had been reported so far. This could be due to the undetected or under-reporting of DSP cases as symptoms of DSP are almost similar to diarrhoea caused by bacterial poisoning. Although not detected in this study, other Paralytic Shellfish Poisoning (PSP) toxin producer such as Gynmodinium catenatum and Alexandrium tamiyavanichi had been reported by Su-Myat et al., 2012 in seawater and sediment samples from Selangor waters. Regular monitoring programs in these areas of Selangor should be implemented to ensure that cockles 
harvested from these areas are safe for consumption.

The heavy metal concentrations in seawater samples from BNO, SB and BSB are shown in Table 4 . The metal abundance in $\mathrm{BNO}$ and $\mathrm{SB}$ were $\mathrm{Zn}>\mathrm{Cu}>\mathrm{As}>\mathrm{Cr}>\mathrm{Hg}>\mathrm{Se}>\mathrm{Cd}>\mathrm{Pb}$. Meanwhile the metal abundance in cockle culture waters fom BSB were $\mathrm{Zn}>\mathrm{As}>\mathrm{Cr}>\mathrm{Cu}>\mathrm{Hg}>\mathrm{Cd}>\mathrm{Se}>\mathrm{Pb}$. The level of $\mathrm{Cr}, \mathrm{Zn}, \mathrm{Cu}, \mathrm{As}$ and $\mathrm{Hg}$ in seawater samples from BNO, SB and BSB collected in Nov, 2014 and Jan, 2015, were higher than the levels stated in the Malaysia Interim Water Quality Standards (MWQCS). These suggest that there could be a fresh disposal of heavy metal waste around the areas at that time. On the other hand, the level of $\mathrm{Se}, \mathrm{Cd}$ and $\mathrm{Pb}$ were low in concentrations and did not exceed the recommended levels. To date, data on heavy metals in shellfish growing waters in Malaysia remain scarce as compared to the availability of data on heavy metal contents in shellfish tissues. Our observation on the high $\mathrm{Zn}$ content in seawater samples from BSB, Kuala Selangor was similar to Koh et al. (2010) who reported concentrations (110.95-139.65 ppm) that exceeded the Malaysian Food Act (1985) permissible levels of Zn (100 ppm) in cockle's tissues from Kuala Selangor. According to Koh et al. (2010), cockle tends to accumulate light metals such as $\mathrm{Zn}$ and $\mathrm{Cu}$ in higher concentration in their tissue than $\mathrm{Pb}, \mathrm{Cd}$ and $\mathrm{Hg}$ due to their significant role as precursors in various enzymatic reactions 
Table 4: Heavy metal concentrations in seawater samples from cockle culture areas at Bagan Nakhoda Omar, Sungai Besar and Bagan Sungai Buloh, Selangor

\begin{tabular}{|c|c|c|c|c|c|c|c|c|c|}
\hline \multirow{2}{*}{$\begin{array}{l}\text { Locati } \\
\text { on }\end{array}$} & \multirow{2}{*}{$\begin{array}{l}\text { Sampli } \\
\text { ng date }\end{array}$} & \multicolumn{8}{|c|}{ Concentrations (ppb) } \\
\hline & & $\mathrm{Cr}$ & $\mathrm{Cu}$ & $\mathrm{Zn}$ & As & $\mathrm{Se}$ & $\mathrm{Cd}$ & $\mathrm{Hg}$ & $\mathrm{Pb}$ \\
\hline Bagan & 20/10/ & & & & $0.01 \pm 0.0$ & $0.08 \pm 0.0$ & & $0.03 \pm 0$ & \\
\hline Nakho & 14 & BD & BD & BD & 0 & 0 & BD & 20 & BD \\
\hline $\mathrm{da}$ & 20/11/ & $23.12 \pm 0$. & $55.75 \pm 0$ & $101.7 \pm 0$ & $28.1 \pm 0.5$ & & $0.03 \pm 0$ & $2.23 \pm 0$ & $0.01 \pm 0$. \\
\hline \multirow[t]{9}{*}{ Omar } & 14 & 55 & 60 & 40 & 0 & ND & 02 & 20 & 00 \\
\hline & $16 / 12 /$ & & & $0.002 \pm 0$ & & $0.06 \pm 0.0$ & & $1.20 \pm 0$ & \\
\hline & 14 & $\mathrm{BD}$ & $\mathrm{BD}$ & 00 & $\mathrm{BD}$ & 1 & $\mathrm{BD}$ & 06 & $\mathrm{BD}$ \\
\hline & 20/1/1 & $20.91 \pm 0$ & $13.22 \pm 1$ & $58.80 \pm 3$ & $24.6 \pm 0.8$ & & $0.08 \pm 0$ & $1.35 \pm 0$ & $0.35 \pm 0$. \\
\hline & 5 & 882 & 9 & 06 & 2 & ND & 04 & 12 & 40 \\
\hline & $17 / 2 / 1$ & & $0.01 \pm 0.0$ & $0.03 \pm 0.0$ & & $0.10 \pm 0.0$ & & $0.70 \pm 0$ & \\
\hline & 5 & $\mathrm{BD}$ & 0 & 1 & $\mathrm{BD}$ & 1 & $\mathrm{BD}$ & 15 & $\mathrm{BD}$ \\
\hline & $18 / 3 / 1$ & $0.05 \pm 0.0$ & $0.04 \pm 0.0$ & $0.10 \pm 0.0$ & $0.05 \pm 0.0$ & $0.07 \pm 0.0$ & & $0.04 \pm 0$ & \\
\hline & 5 & 0 & 0 & 0 & 2 & 02 & BD & 01 & BD \\
\hline Sungai & 20/10/ & & & $0.19 \pm 0.0$ & $0.01 \pm 0.0$ & $0.08 \pm 0.0$ & & $0.30 \pm 0$ & \\
\hline \multirow[t]{11}{*}{ Besar } & 14 & $\mathrm{BD}$ & $\mathrm{BD}$ & 0 & 0 & 05 & $\mathrm{BD}$ & 20 & $\mathrm{BD}$ \\
\hline & 20/11/ & $24.22 \pm 0$. & $30.19 \pm 0$ & $70.40 \pm 0$ & $29.6 \pm 0.6$ & & $0.01 \pm 0$ & $2.22 \pm 0$ & \\
\hline & 14 & 5 & 5 & 10 & 3 & ND & 02 & 20 & BD \\
\hline & $16 / 12 /$ & $22.70 \pm 0$ & $14.90 \pm 0$ & $54.82 \pm 1$ & $22.87 \pm 0$ & & $0.03 \pm 0$ & $1.20 \pm 0$ & \\
\hline & 14 & 6 & 90 & 00 & 32 & ND & 02 & 06 & BD \\
\hline & $20 / 1 / 1$ & $21.10 \pm 0$. & $14.32 \pm 0$. & $57.91 \pm 0$ & $24.5 \pm 0.4$ & & $0.05 \pm 0$ & $1.32 \pm 0$ & \\
\hline & 5 & 49 & 30 & 30 & 1 & ND & 01 & 10 & BD \\
\hline & $17 / 2 / 1$ & & $0.01 \pm 0.0$ & $0.03 \pm 0.0$ & & $0.11 \pm 0.0$ & & $0.77 \pm 0$ & \\
\hline & 5 & BD & 0 & 0 & BD & 06 & BD & 10 & BD \\
\hline & $18 / 3 / 1$ & & $0.04 \pm 0.0$ & & & $0.07 \pm 0.0$ & & $0.01 \pm 0$ & \\
\hline & 5 & $\mathrm{BD}$ & 0 & $0.1 \pm 0.00$ & $0.1 \pm 0.00$ & 01 & $\mathrm{BD}$ & 00 & $\mathrm{BD}$ \\
\hline Bagan & $20 / 10 /$ & & & & $0.004 \pm 0$ & $0.04 \pm 0.0$ & & $0.29 \pm 0$ & \\
\hline Sungai & 14 & BD & $\mathrm{BD}$ & BD & 00 & 1 & $\mathrm{BD}$ & 21 & BD \\
\hline \multirow[t]{10}{*}{ Buloh } & 20/11/ & $24.70 \pm 0$. & $19.30 \pm 1$ & $71.50 \pm 1$ & $28.4 \pm 0.4$ & & & $0.5 \pm 0.1$ & \\
\hline & 14 & 20 & 20 & 70 & 4 & ND & $\mathrm{BD}$ & 0 & $\mathrm{BD}$ \\
\hline & $16 / 12 /$ & & & & & $0.07 \pm 0.0$ & & $0.02 \pm 0$ & \\
\hline & 14 & $\mathrm{BD}$ & $\mathrm{BD}$ & $\mathrm{BD}$ & $\mathrm{BD}$ & 04 & $\mathrm{BD}$ & 00 & $\mathrm{BD}$ \\
\hline & $20 / 1 / 1$ & $20.81 \pm 0$ & $13.15 \pm 0$. & $57.3 \pm 1.1$ & $24.50 \pm 0$ & & $0.06 \pm 0$ & $0.70 \pm 0$ & \\
\hline & 5 & 70 & 50 & 0 & 60 & ND & 10 & & $\mathrm{BD}$ \\
\hline & $17 / 2 / 1$ & & $0.01 \pm 0.0$ & $0.03 \pm 0.0$ & & $0.11 \pm 0.0$ & & $0.61 \pm 0$ & \\
\hline & 5 & $\mathrm{BD}$ & 0 & 0 & BD & 1 & BD & 08 & BD \\
\hline & $18 / 3 / 1$ & $0.01 \pm 0.0$ & $0.04 \pm 0.0$ & $0.10 \pm 0.0$ & $0.08 \pm 0.0$ & $0.07 \pm 0.0$ & & & \\
\hline & 5 & 0 & 0 & 0 & 0 & 02 & $\mathrm{BD}$ & $\mathrm{BD}$ & $\mathrm{BD}$ \\
\hline \multicolumn{10}{|c|}{ Malaysia } \\
\hline \multicolumn{10}{|c|}{ Interim $\mathrm{W}$} \\
\hline \multicolumn{10}{|c|}{ Quality } \\
\hline \multicolumn{10}{|c|}{$\begin{array}{l}\text { Standards } \\
\text { (MWOCS) }\end{array}$} \\
\hline
\end{tabular}

BD-below detection limit

ND-not detected 


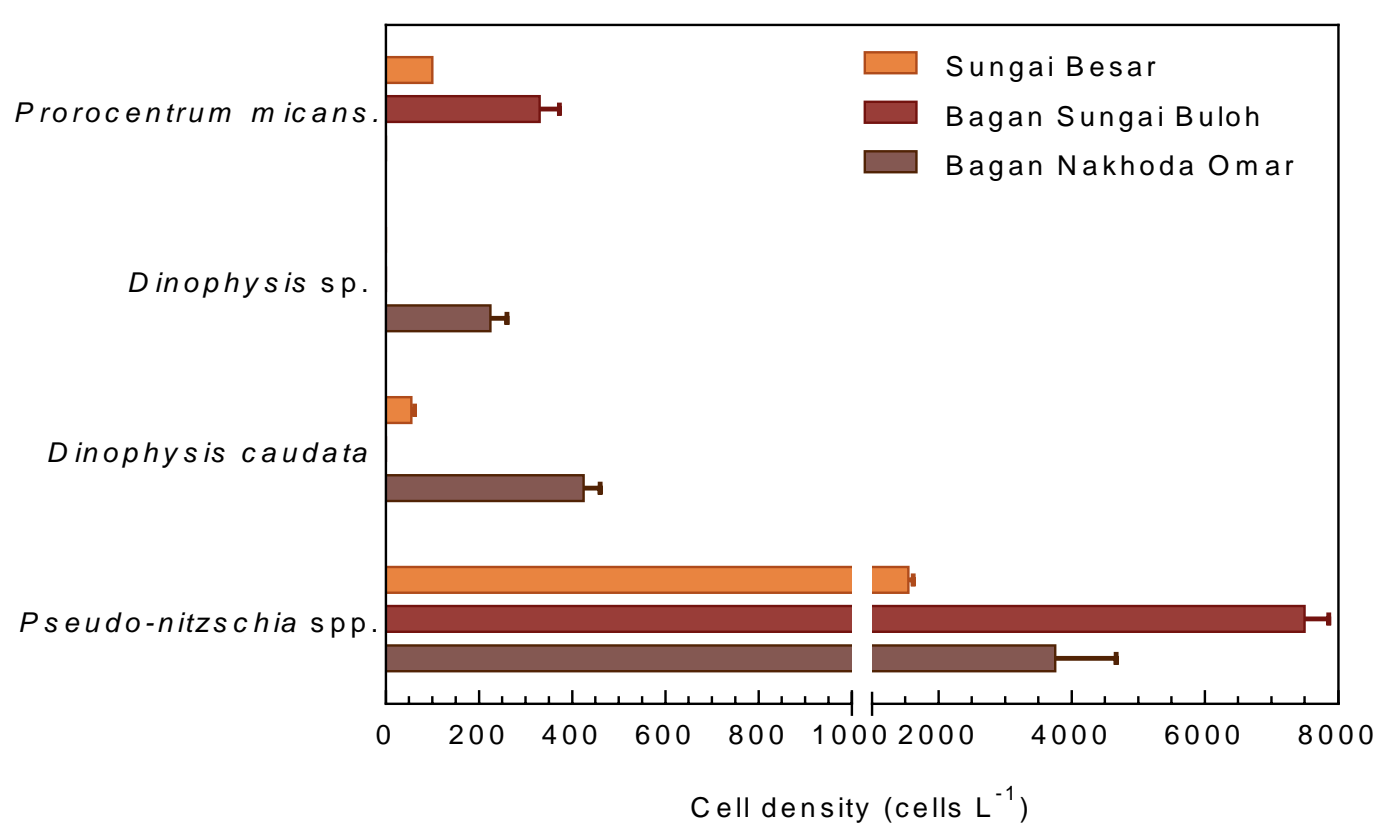

Figure 4: Mean cell densities of potentially toxic phytoplankton by sampling site

\section{CONCLUSION}

In conclusion, this study provides the baseline information on the food safety aspects of the blood cockle (Tegillarca granosa) and its culture waters at BNO, SB and BSB. The results from this study indicate that the cockles from BNO, SB and BSB could only be sold for human consumption after re-laying them in cleaner water and to be followed by purification or heat treatment processes. The shellfish areas at BNO, SB and BSB can be classified as conditionally approved. There is a trend indicating an increase of fecal pollution in SB. Further investigation should be carried out to identify the primary source of pollution and their occurrences throughout the year so that appropriate and cost-effective corrective actions could be taken to prevent future pollution and adverse effect to the public.

\section{REFERENCES}

1. Ahmed, F.E. (1991). Seafood Safety. Committee on the evaluation of the safety of fishery products. Food and Nutrition Board, Washington National Academy Press.

2. Alias, M. (2015). Determination of carrying capacity and appropriate stocking density for cockle farming in Selangor. Paper presented at JIRCAS Seminar 2-3 Dis 2015, King Mongkut's Institute of Technology Ladkrabang, Bangkok, Thailand.

3. Annual Fisheries Statistics. (2008; 2010). Available at www.dof.gov.my.

4. APHA (American Public Health Association), (1998). Standard Method for the Examination of Water and Wastewater, 4th Edition. Clesceri, L.S, Greenberg, A.E. and Eaton, A.D. (Editors). American Water Works Association (AWWA) 
\& Water Environment Federation (WEF), Washington, D.C. 1325 pp.

5. APHA (American Public Health Association), (2001). Compendium of Methods for the Microbiological Examinations of Food, 4th edition. F.P. Downes and K. Ito (Editors). American Public Health Association, Washingon D.C, US.

6. Balech, E. (1995). The Genus Alexandrium Halim (Dinoflagellata). Sherkin Island Marine Station Special Publication, Cork, Ireland, 1-151 pp.

7. Booyapiwat, S. (1997). Distribution, Abundance and Species Composition of phytoplankton in the South China Sea, Area I: Gulf of Thailand and East Coast of Peninsular Malaysia. Proceedings on Marine Fishery Resources survey in the South China Sea, Area I: Gulf of Thailand and East Coast of Peninsular Malaysia. 24-26 November 1997, Bangkok, Thailand, 111-134 pp.

8. Carter, C.M., Ross, A.H., Schielb, D.R., Howard-William, C. \& Haydena, B. (2005). In situ microcosm experiments on the influence of nitrate and light on phytoplankton community composition. Journal of Experimental Marine Biology and Ecology 326: 1-13.

9. European Committee Directives (91/492/EEC of 15 July 1991). Available at http://eugbc.net/wpcontent/uploads/2014/03/3Com.2CouncilDirective91-492-EEC.pdf

10. Goswami, B.B., Koch, W.H. \& Cebula, T.H. (1993). Detection of hepatitis A virus in Mercenaria mercenaria by coupled reverse transcription and polymerase chain reaction. Applied and Environmental Microbiology 59: 2765-2770.
11. Holmes, M.J. \& Teo, S.L.M. (2002). Toxic marine dinoflagellates in Singapore waters that cause seafood poisonings. Clinical and Experimental Pharmacology and Physiology 29: 829-836.

12. Koh, S. M., Koh P. K., Sim. K.T., Lee, Y.H. \& Surif, S. (2010). Proximate analysis and heavy metal concentrations of tissues of cockles (Anadara granosa) from several cockle farms in Peninsular Malaysia. Sains Malaysiana 40(2): 139-146.

13. Latha, N. \& Ramachandra M. (2013). Microbial pollution- total coliform and fecal coliform of Kengeri lake, Bangalore region Karnataka, India. International Journal of Scientific and Research Publications, Vol 3 Issue 11: 1-3.

14. Lim, H.C., Leaw C.P., Su, S.N.P., Teng, S.T., Usup, G., MohammadNoor, N., Lundholm, N., Kotaki, Y. \& Lim, P.T. (2012). Morphology and molecular characterization of Pseudo-nitzschia (Bacillariophyceae) from Malaysian Borneo, including the new species Pseudo-nitzschia circumpora sp. nov. Journal of Phycology 48(5): 1232-1247.

15. Majbritt, F.L., Mette, E.B., Atherine, R., Fatimaj, Y. \& Muhamed, S. (2004). Phytoplankton Community Composition and Size Distribution in the Langat River Estuary, Malaysia. Estuaries 27(4): 716-727.

16. Malaysia Food Regulation (1985). Malaysian law on food and drugs. Malaysian Law Publishers

17. Method 200.8, Revision 5.4: Determination of Trace Elements in Waters and Wastes by Inductively Coupled Plasma Mass Spectrometry (1994). United States Environmental Protection Agencies. 
18. Method 6020 Inductively Coupled Plasma - Mass Spectrometry (1998). United States Environmental Protection Agencies.

19. Mohammad-Noor, N., Anton, A. \& Mat Amin N. (2007). Biodiversity of dinoflagellates in the coastal waters off Malacca, Peninsular Malaysia. The Journal of Science \& Technology 21: 12-18

20. Mohd Fadzil, S.R., Faizal, Riza A.H. \& Mohd Nasir, S. (2010). Declining production of cockles in relation to ammonia concentrations in Sungai Buloh River, Selangor. Journal of Environment and Earth Science Vol. 3, No.10.

21. Omura, T., Iwataki, M., Borja, V.M., Takayama, H.\& Fukuyo Y. (2012). Marine Phytoplankton of the Western Pacific. Kouesiha Kouseikaku Co. Ltd, Tokyo.

22. Othman, F, Uddin Chowdhury, M.S. \& Sakai, N. (2014). Assessment of microorganism pollution of Selangor River, Malaysia. International Journal of Advances in Agricultural \& Environmental Engineering. . 1, (2): 2003-2007

23. Polat, S. (2007). Effects of nutrient enrichment on coastal phytoplankton composition and abundance in the Northeastern Mediterranean. Pakistan Journal Botany 39(6): 2087-2095.

24. Roziawati, M.R. \& Faazaz, A.L. (2011). Potentially harmful microalgae from cockle culture area in Sg. Jarum Mas, Perak. Malaysian Fisheries Journal 10: 91-103.

25. S Kit ELISA for Paralytic Shellfish Poison, Shin Nihon Kentei Kyokai, 2-12-13, Shinyokohama Kohoku, Yokohama, Kanagawa, 222-0033.

26. Sasikumar, G. \& Krishnamoorthy, M. (2010). Feacal indicators and sanitary quality of shellfish harvesting environment: influences of seasonal monsoon and riverrunoff. Indian Journal of Marine Sciences, Vol 39 (3): 434-444

27. Shimoda, T. (2015). Nutrients supply and its environment in Selangor cockle culture grounds. Paper presented at JIRCAS Seminar 2-3 Dis 2015, King Mongkut's Institute of Technology Ladkrabang, Bangkok, Thailand.

28. Su-Myat, Yurimoto, T., Hinode, K., Takata, Y., Mohd Nor Azman, A., Alias, M., Maeno, Y., Kodama, M., Koike, K. \& Matsuoka, K. (2012). Finding of Toxic Gymnodinium catenatum Graham and Alexandrium tamiyavanichii

Balech

(Dinophyceae) from Coastal Waters of Selangor, Peninsular Malaysia. Malaysia Fisheries Journal 11: 3241.

29. Tek, Y.H. 2009. Comparison of extraction methods for detecting hepatitis A virus in shellfish (Mytilus galloprovincialis) using tissue culture titration, RT-Nested PCR and real time RT-PCR. Master of Science Thesis, University Putra Malaysia.

30. Teng S.T., Leaw C.P., Lim H.C. \& Lim P.T. (2013). The genus Pseudonitzschia (Bacillariophyceae) in Malaysia, including new records and a key to species inferred from morphology-based phylogeny. Botanica Marina 56(4): 375-398.

31. Teng S.T., Lim H.C., Lim P.T., Dao V.H., Bates S.S. \& Leaw C.P. (2014). Pseudo-nitzschia kodamae sp. nov. (Bacillariophyceae), a toxigenic species from the Strait of Malacca, Malaysia. Harmful Algae 34: 17-28.

32. Toh, T.H., Lim, P.T., Roziawati, M.R. \& Leaw C.P. (2013). Harmful algal 
species in the Tebrau Strait: an SEM observation of the dinoflagellates assemblage. Annals of Microscopy 13: 4-13.

33. US National Shellfish Sanitation Program (NSSP) (Revision). (2013). Available at http://www.fda.gov/Food/Guidance Regulation/Federal State Food Programs/ucm2006754.htm.

34. Vilarińo, M. L., Le Guyader, F. S., Polo, D., Schaeffer, J., Kröl, J. and
Romalde, J. L. 2009. Assessment of human enteric viruses in cultured and wild bivalve mollusks. International Journal of Microbiology 12: 145-151.

35. Yurimoto, T., Faizul, M.K., Fuseya R. \& Alias M. (2014). Mass mortality event of the blood cockle, Anadara granosa, in aquaculture ground along Selangor coast, Peninsular Malaysia International Aquatic Research 6:177-186. 